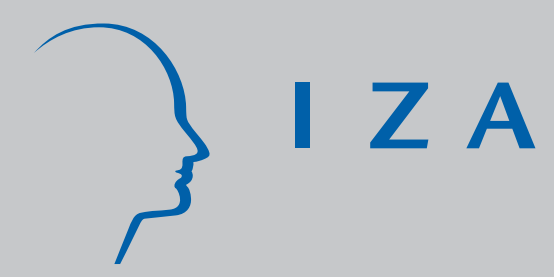

IZA DP No. 168

Social Harmony at the Boundaries of the Welfare State: Immigrants and Social Transfers

Gil S. Epstein

Arye L. Hillman

June 2000 


\title{
Social Harmony at the Boundaries of the Welfare State: Immigrants and Social Transfers
}

\author{
Gil S. Epstein \\ Department of Economics, Bar-Ilan University, Israel, CEPR, London and IZA, Bonn
}

Arye L. Hillman

Department of Economics, Bar-Ilan University, Israel, CEPR, London

Discussion Paper No. 168

June 2000

\author{
IZA \\ P.O. Box 7240 \\ D-53072 Bonn \\ Germany \\ Tel.: +49-228-3894-0 \\ Fax: +49-228-3894-210 \\ Email: iza@iza.org
}

This Discussion Paper is issued within the framework of IZA's research area The Welfare State and Labor Markets. Any opinions expressed here are those of the author(s) and not those of the institute. Research disseminated by IZA may include views on policy, but the institute itself takes no institutional policy positions.

The Institute for the Study of Labor (IZA) in Bonn is a local and virtual international research center and a place of communication between science, politics and business. IZA is an independent, nonprofit limited liability company (Gesellschaft mit beschränkter Haftung) supported by the Deutsche Post AG. The center is associated with the University of Bonn and offers a stimulating research environment through its research networks, research support, and visitors and doctoral programs. IZA engages in (i) original and internationally competitive research in all fields of labor economics, (ii) development of policy concepts, and (iii) dissemination of research results and concepts to the interested public. The current research program deals with (1) mobility and flexibility of labor markets, (2) internationalization of labor markets and European integration, (3) the welfare state and labor markets, (4) labor markets in transition, (5) the future of work, (6) project evaluation and (7) general labor economics.

IZA Discussion Papers often represent preliminary work and are circulated to encourage discussion. Citation of such a paper should account for its provisional character. 
IZA Discussion Paper No. 168

June 2000

\section{ABSTRACT \\ Social Harmony at the Boundaries of the Welfare State: Immigrants and Social Transfers*}

The social contract of the welfare state can be strained by the arrival of immigrants who receive welfare payments financed by citizens' taxes. We show, however, that the presence of unemployed immigrants receiving welfare payments is consistent with social harmony. The social harmony, which is a consequence of a view of unemployment as a labor-market discipline, contrasts with the social conflict predicted by Karl Marx when he proposed his earlier version of the same explanation for unemployment. We demonstrate that a socially harmonious policy is always feasible. Outcomes without social harmony can therefore always be suitably amended.

JEL Classification: $\quad$ I38, F22, P16

Keywords: Welfare state, social harmony, immigrants

Gil S. Epstein

Department of Economics

Bar-Ilan University

52900 Ramat-Gan

Israel

Tel: $+972-3-531-8937$

Fax: +972-3-535-3180

Email: epsteig@mail.biu.ac.il

\footnotetext{
* Acknowledgements: We thank our colleagues Joseph Deutsch, Abraham Lioui and Avi Weiss for helpful comments.
} 
"Nationalism and xenophobia of the kind that underpinned big election gains last year for the Swiss and Austrian far right have always existed in Europe. What is new is the return of what was repressed." Ruth Dreifuss, President of Switzerland, quoted in the Herald Tribune, January 24, 2000.

\section{Introduction}

The welfare state can be understood as a social contract. Under the terms of the contract, in return for taxes paid, citizens are provided with insurance by the state against adverse outcomes during the course of their lifetimes (see Hans-Werner Sinn 1995). The social contract can however be compromised, by disincentives of high taxes when welfare programs are financed, and by moral hazard when the welfare expenditures are made (see Assar Lindbeck, 1994; for a critical view of the welfare state, see Erich Weede 1998).

The boundaries of the social contract are, in particular, tested when welfare programs provide support for unemployed immigrants. Taxpayers who accept the social contract as providing insurance for fellow citizens might take the view that foreign citizens are outside of the domain of the domestic contract. While means might therefore be sought of resolving the moral hazard problems within the society, ${ }^{1}$ the presence of immigrants who receive welfare payments might be interpreted as adverse selection in locational response to the incentives of the welfare state.

When this is the interpretation, the consequence can be social tension. Such tensions have, in the 1990s (see the introductory quote), been reflected in election gains in some European countries for political parties taking anti-immigrant positions. We offer an alternative to the social tensions. We show that the social tensions can be misplaced, and present a picture of social harmony consistent with unemployed immigrants supported by the state.

Whether there is social tension or social harmony depends on the reason why immigrants are perceived to be unemployed. An economic basis for social tension is James Buchanan's model of a Samaritan's dilemma (1975). Buchanan describes a kind person with a social conscience and another person whom he pre-labels a

\footnotetext{
1 Substantial attention has been directed at considering how the welfare state might be sustained. See for example Dennis Snower (1993, 1996).
} 
"parasite". ${ }^{2}$ The kind person derives personal satisfaction from helping disadvantaged people and confronts a decision whether to provide income-support for the parasite. The "parasite" confronts the decision whether to be self-reliant and to seek employment. The kind person derives satisfaction from assisting the disadvantaged, and certainly does not wish to see anybody starve. The result is that the kind person has a dominant strategy of giving, which allows the parasite to choose not to work and to live off the kind person's benefaction. The kind person is unhappy with this outcome, and would prefer to give but also that the welfare recipient make an attempt to be self-reliant.

The source of social tension is not that the Samaritan in Buchanan's model is obliged to give. The Samaritan likes to give (see also James Andreoni 1990 on warmglow feelings of charitable giving). The social tension is due to decision of the parasite to take advantage of the good character of the Samaritan by choosing to remain unemployed. Buchanan's dilemma does not arise in a welfare state where individuals adhere to a social norm of self-reliance and unemployment is a random adverse outcome for the state's citizens. ${ }^{3}$

Social tensions do not require the conditions of Buchanan's Samaritan's dilemma, where some people are described as having a pre-disposition not to work. The tensions can also be present if immigrants seek employment but fail to find jobs. Taxpayers who fund welfare programs may still nonetheless take the view that unemployed immigrants should seek assistance in the jurisdiction that is the domain of their own social contract. This may of course not be possible. ${ }^{4}$

\footnotetext{
${ }^{2}$ We may not agree with the labels placed on the players in Buchanan's game: the parasite is a parasite before he or she has chosen in the equilibrium of the game to be a parasite, and the Samaritan is by nature good with reference to a story where other people are presumed to be by nature not good. We have nonetheless retained Buchanan's labels from his original exposition.

${ }^{3}$ See Lindbeck, Nyberg, and Weibull (1997) for a description of a society where self-reliance through employment is the social norm. They show that how a society fares depends on the proportion of people in the population who adhere to the social norm.

${ }^{4}$ The immigrants may have left less benevolent jurisdictions. See Epstein, Hillman, and Ursprung 1999.
} 


\section{The efficiency wage and the reserve army}

Social tensions are unfortunate and unappealing. Economic theory can fortunately present us with a more benevolent interpretation of unemployed immigrants supported by the state -- without appeal to altruism. An appealing picture of social harmony follows from an efficiency-wage explanation for unemployment. Unemployment is then the outcome of the information structure of employeremployee relationships. ${ }^{5}$ Workers, whose effort is discretionary and who prefer not to exert themselves, can be monitored by employers only at a cost. With no monitoring, and with full employment, workers choose to shirk. To induce effort, employers pay workers in excess of the market-clearing wage. The excess wage payment promotes efficiency by introducing a penalty if a worker is found shirking. A worker who through the limited monitoring that takes place is found shirking is dismissed. The dismissed worker joins the ranks of the unemployed, and is replaced by someone who was previously unemployed. The equilibrium is that, when faced with the anticipation of personal loss due to transfer from employment to the unemployment pool, no employed worker chooses to shirk. ${ }^{6}$

Karl Marx also expressed the sentiment that unemployed workers act as a discipline on employed workers (Capital 1887, Chapter 25, Section 4). Marx proposed that employers maintain a "reserve army" of unemployed workers, who when massed at the factory gates act as a discipline on the workers employed inside the factory:

"Every labourer belongs to it (the reserve army) during the time he is only partially employed or wholly unemployed" (p. 600).

The reserve army of the unemployed is "torment" of workers:

"The same causes which develop the expansive power of capital develop also the labor power at its disposal. The relative mass of the industrial reserve army increases therefore with the potential energy of wealth. But the greater this reserve army in proportion to the active labour army, the

\footnotetext{
${ }^{5}$ A credible model views unemployment as rent protection by insiders (see Assar Lindbeck and Dennis Snower 1988). In the concluding section, we note the implications for social tension and social harmony from a juxtaposition of efficiency wage and insider-outsider theories.

${ }^{6}$ See Carl Shapiro and Joseph Stiglitz (1984) for an expanded exposition of this model.
} 
greater is the mass of a consolidated surplus production, whose misery is in inverse relation to its torment of labor" (p. 603).

Marx's view of unemployment as a discipline on employed workers is part of his theme of conflict between workers and owners of capital. Owners of capital, as employers, exploit workers in a conspiracy that makes workers act as disciplinarians on their own class. Marx did not refer to an efficiency wage. He viewed workers as receiving subsistence wages. ${ }^{7}$

Marx's conflict between workers and owners of capital in a society disappears when the reserve army consists of persons outside of the society's domain. We shall portray government as choosing immigration policy and welfare benefits to maximize a society's welfare defined over the utilities of the society's national workers and capital owners. ${ }^{8}$ Workers and capital owners seek different preferred policies, and the social welfare function reflects the social compromise between the different outcomes sought by the two parts of the society. Immigration policies invariably benefit owners of capital, and the social compromise establishes the magnitude of the benefit to domestic labor. An immigration that makes for social harmony by providing mutual benefit to workers and capital owners exists, and so can be chosen.

We impose all taxes to finance welfare payments on employed workers - who by appropriate policy nonetheless gain from the presence of unemployed immigrants. A domestic employed worker can lose if displaced in employment by an immigrant. In that case, however, the argument against immigrants cannot be that they are an unwelcome burden on taxpayers.

We proceed as follows. In section 3 we set out an unemployment-as-discipline model and consider the consequences of immigration. In section 4 we introduce discretionary government policy and show that a policy that assures social harmony is always feasible, so that, if there is not social harmony, it is because the socially harmonious policy has not been chosen.

\footnotetext{
${ }^{7}$ Marx's conspiracy theory would seem to require collusion among employers to maintain the reserve army. The modern efficiency-wage hypothesis does not require cooperation (collusion) among employers. The discipline of the reserve army on employed workers arises from non-cooperative Nash behavior among employers.

${ }^{8}$ Some possible outcomes may however oblige us to interpret policy as reflecting electoral rather than social welfare objectives.
} 


\section{The Model}

We adopt standard conditions that provide a stationary structure for an efficiency-wage model. A population consists of owners of capital and workers. Workers consist of $N_{L}$ nationals and $N_{F}$ immigrants. Workers are risk neutral and averse to effort. A worker's utility function is separable and linear in private consumption provided by the wage $w$ and in the level of effort $e$,

$$
U(w, e)=w-e .
$$

The effort choice is dichotomous: effort is either zero or a positive level. A worker who is unemployed receives benefits of $w_{o}$ from the state, and has no need to exert effort so $e=0$. Welfare payments are the same for nationals and immigrants. An immigrant has greater expected income than in the country he or she has left. ${ }^{9}$

A worker of type $j(j=F, L)$ has a probability of $p_{j}$ of leaving employment for exogenous reasons that do not depend on the employer. Such a worker enters the unemployment pool. All workers maximize present discounted utility, with a rate of time preference $r>0$. The model is set in continuous time. The only choice that a worker is required to make is selection of effort $e$. A worker who does not shirk performs at a customary level of effort for the job, receives the wage $w$, and retains his or her job until exogenous factors cause a separation. Employers imperfectly monitor the effort of workers. A worker who chooses to shirk is detected and fired with probability per unit of time $q$.

$V_{e}(s, j)$ and $V_{e}(n, j)$ are expected lifetime utilities of an employed worker of type $j$ when shirking $(s)$ and when not $(n) . \quad V_{u}$ is the expected lifetime utility of an unemployed person.

For a shirker,

$$
r V_{e}(s, j)=w-\left(p_{j}+q\right)\left(V_{e}(s, j)-V_{u}\right)
$$

and for a non-shirker,

\footnotetext{
${ }^{9}$ In this model the state observes individual outcomes and distributes income for private consumption. The model therefore abstracts from the role of the state in providing public goods. If immigrants are poorer on average than national residents, there are also implications the burden of voluntary provision of public goods (see Kai Konrad 1994).
} 


$$
r V_{e}(n, j)=w-e-p_{j}\left(V_{e}(n, j)-V_{u}\right)
$$

From (2) and (3), we have:

$$
V_{e}(s, j)=\frac{w+\left(p_{j}+q\right) V_{u}(j)}{r+p_{j}+q}
$$

and

$$
V_{e}(n, j)=\frac{(w-e)+p_{j} V_{u}(j)}{r+p_{j}}
$$

A worker will choose not to shirk, if and only if expected lifetime discounted utility is greater when not shirking than when shirking: that if and only if $V_{e}(s, j) \leq V_{e}(n, j)$. No shirking takes place if

$$
w \geq r V_{u}(j)+\frac{\left(r+p_{j}+q\right)}{q} e
$$

This is the non-shirking condition.

Firms' production functions are $\tilde{f}(\bar{K}, L)$ where $\bar{K}$ is available capital and $L$ is the number of employed workers. Owners of capital (or employers) gain when more workers are employed. ${ }^{10}$ Demand for workers is given by their value of marginal product, and is a decreasing function of the wage $w$. An equilibrium is defined as an outcome where owners of capital, taking as given wages and employment levels at the other firms, find it optimal to offer the going wage rather than a different wage. That is, there is a Nash equilibrium in wages paid by employers. The sole variable determining employers' decisions is the disciplining of employed workers through $V_{u}$, the expected utility of being an unemployed worker.

Since all unemployed workers receive the same welfare benefits $w_{o}, V_{u}$ is common to all employees. An unemployed person's utility is thus independent of the identity of his or her previous employer. Hence

$$
r V_{u}(j)=w_{0}+k_{j}\left(V_{e}(j)-V_{u}(j)\right)
$$

\footnotetext{
${ }^{10}$ Because of diminishing marginal product of labor.
} 
where $k_{j}$ is the rate at which workers who are unemployed find jobs and $V_{e}(j)$ is the expected utility of an employed worker of type $j$, which in equilibrium equals to $V_{e}(n, j)$. Substituting (7) into (5), we obtain

$$
r V_{e}(j)=\frac{(w-e)\left(k_{j}+r\right)+w_{o} p_{j}}{k_{j}+p_{j}+r} \text { and } r V_{u}(j)=\frac{(w-e) k_{j}+w_{o}\left(r+p_{j}\right)}{k_{j}+p_{j}+r}
$$

Then, substituting (8) into (6), we determine that worker $j$ will not shirk if

$$
w \geq w_{o}+e+\frac{e}{q}\left(k_{j}+p_{j}+r\right)
$$

The efficiency wage is defined as the lowest wage that satisfies (9). Such a wage is sufficiently high that it is not worthwhile for an employed worker to shirk.

From (9), we see that the efficiency wage increases: (1) as the probability of detection $q$ decreases; (2) the greater is effort $e$; (c) the higher is the quit rate, $p_{j}$; the higher is the rate of time preference $r$; (4) the higher are welfare or unemployment benefits $w_{o}$; and (5) the higher the flows out of unemployment $k_{j}$.

To express the efficiency wage as depending on the level of unemployment, we denote by $L_{j}$ total employment of individuals of group $j$ and by $N_{j}$ the total potential labor supply of group $j$, with $N_{L}>N_{F}$. In a stead-state, the flow into the unemployment pool for each of the groups is $p_{j} L_{j}$. The flow out of unemployment per unit of time is $K j(N j-L j)$. Since these must be equal,

$$
k_{j}=p_{j} \frac{L_{j}}{N_{j}-L_{j}}
$$

The probability of job loss independent of the employer's decision quit rate, $p_{j}$, is an increasing function of the rate of employment $L / N$ where $N=N_{L}+N_{F}$ and $L=L_{L}+L_{F}$. This is so, since the higher is employment (or the lower is unemployment), the more willing is a worker to leave a job for extraneous personal reasons. We can thus express the separation rate $p_{j}$ as an increasing function of employment,

$$
p_{j}=f_{j}\left(\frac{L}{N}\right) \quad \text { such that } \frac{\partial\left(f_{j}\left(\frac{L}{N}\right)\right)}{\partial\left(\frac{L}{N}\right)}>0
$$


Now substituting for $p_{j}$ from (11) into (10) and then into (9), we obtain that the condition that a worker of type $j$ will not shirk as

$$
w \geq w_{o}+e+\frac{e}{q}\left(f_{j}\left(\frac{L}{N}\right) \frac{N_{j}}{\left(N_{j}-L_{j}\right)}+r\right) \quad .
$$

The equilibrium efficiency wage is then the wage where (12) holds with equality.

We see that immigration affects the efficiency wage through

$$
\begin{aligned}
\frac{\partial w}{\partial N_{F}} \geq \frac{e}{q} \frac{\partial f_{j}\left(\frac{L}{N}\right)}{\partial N_{F}} \frac{\left(\frac{\partial L}{\partial N_{F}} N-L\right)}{N^{2}} \frac{N_{j}}{\left(N_{j}-L_{j}\right)}= \\
\quad=\frac{e}{q} \frac{\partial f_{j}\left(\frac{L}{N}\right)}{\partial N_{F}} \frac{(\eta-1) L}{N^{2}} \frac{N_{j}}{\left(N_{j}-L_{j}\right)}
\end{aligned}
$$

$\eta$ is here the elasticity of the aggregate employment with respect to the potential work force. ${ }^{11}$ In the efficiency-wage model, $\eta<1$ : that is, the number of employed workers cannot increase proportionately more than an increase in the total potential workforce.

Hence an increased presence of immigrants implies greater unemployment. Immigration thereby enhances the disciplining effect of the reserve army (to use Karl Marx's term), and in (13) the efficiency wage falls. We have our first conclusion about immigration:

\section{Proposition 1}

The willingness of local workers to exert effort increases with the number of immigrants.

Proposition 1 expressed the consequence that increasing the number of immigrants offering themselves for employment in the economy increases the cost of

$$
{ }^{11} \eta=\frac{\partial L}{\partial N_{F}} \frac{N}{L}=\frac{\partial N}{\partial N_{F}} \frac{\partial L}{\partial N} \frac{N}{L} \text { while } \frac{\partial N}{\partial N_{F}}=1 \text {. }
$$


shirking to local workers, because of the lower probability of finding a new job if an employed worker is fired. The lower equilibrium wage consistent with non-shirking is demonstrated in figure 1, which shows the demand function for workers $D$ and the original pre-immigration willingness-to-exert-effort function $E$. An increase in the number of immigrants shifts the willingness-to-exert-effort function downward to $E_{1}$. After the downward shift in this function, for any value of $L$, the efficiency wage w is lower.

\section{Welfare benefits}

We now establish how welfare benefits affect the equilibrium. Suppose that

$$
p_{j}=f_{j}\left(\frac{L}{N}\right)=\frac{f_{j}(L)}{N}
$$

so that the steady-state relationship (10) is

$$
k_{j}=\frac{f_{j}}{N} \frac{L_{j}}{\left(N_{j}-L_{j}\right)}
$$

Substituting for $k_{j}$ from (14) into (9) indicates that a worker of type $j$ will not shirk if

$$
w \geq w_{o}+e+\frac{e}{q}\left(f_{j} \frac{N_{j}}{\left(N_{j}+N_{i}\right)\left(N_{j}-L_{j}\right)}+r\right) \quad \forall j \neq i \text { and } j, i=L, F
$$

The two equations represented by (16) imply a willingness-to-exert effort function for immigrants

$$
L_{F}=N_{F}-\frac{N_{F} f_{F} e}{N\left(q w-q w_{o}-e r-e q\right)}
$$

and for nationals

$$
L_{L}=N_{L}-\frac{N_{L} f_{L} e}{N\left(q w-q w_{o}-e r-e q\right)}
$$

Adding, we have the aggregate function

$$
L=L_{L}+L_{F}=N-\frac{\left(N_{L} f_{L}+N_{F} f_{F}\right) e}{N\left(q w-q w_{o}-e r-e q\right)}
$$


From equation (9), we know that $q w-q w_{o}-e r-e q>0$. In (19), we accordingly observe that the positive relation between efficiency wage $w$ and willingness-to-exerteffort that underlies the efficiency wage hypothesis. We also observe, perhaps not unexpectedly, that the higher are welfare payments, the lower is willingness to exert effort.

\section{Labor-market equilibria}

From (17) and (18):

$$
\frac{\partial L_{L}}{\partial N_{F}}=\frac{N_{L} f_{L} e}{N^{2}\left(q w-q w_{o}-e r-e q\right)}>0
$$

and

$$
\frac{\partial L_{L}}{\partial N_{L}}=1-\frac{N_{F} f_{L} e}{N^{2}\left(q w-q w_{o}-e r-e q\right)}>0
$$

Looking at figure 1, we see that, before the arrival of immigrants, the number of employed local workers was $L_{L}{ }^{0}$ with an efficiency wage of $w^{0}$. The presence of $N_{F}$ immigrants increases local workers' willingness-to-exert effort, and the equilibrium wage falls from $w^{0}$ to $w^{1}$, with $L^{1}$ the new equilibrium aggregate willingness-to-exert effort function.

The lower wage affects demand for labor, and also affects effort. Employment responds to the respective elasticities. When effort does not decline precipitously in response to the lower wage, and when demand for labor is sufficiently elastic, employment increases. $^{12}$ In Figure 1, employment of local workers increases from $L_{L}{ }^{0}$ to $L_{L}{ }^{1}$. The increase in employment benefits national workers. Suppose that national workers have priority in exit from the disciplining unemployment pool. Then:

\footnotetext{
12 Completely inelastic demand would of course allow for no increase in employment, nor would an extreme effort response. See the appendix.
} 
When more immigrants arrive and populate the reserve army, they "push" national workers out of the reserve army into employment - although employment is at a lower wage (otherwise they would not have been demand for the additional employment).

\section{The financing of welfare benefits}

We now specify how welfare benefits are financed. Suppose the benefits are financed by taxation of employed labor. With the same welfare benefits $w_{o}$ paid to local and immigrant workers, the tax per employed worker to finance the welfare payments is: ${ }^{13}$

$$
\operatorname{Tax}=\frac{(N-L)}{L} w_{o}=\frac{\left(N_{L}+N_{F}-L_{L}-L_{F}\right)}{L_{L}+L_{F}} w_{o}
$$

Employed workers do not shirk if

$$
w \geq w_{o}\left(1+\frac{N-L}{L}\right)+e+\frac{e}{q}\left(f_{L}\left(\frac{L}{N}\right) \frac{N_{L}}{\left(N_{L}-L_{L}\right)}+r\right)
$$

An increase in the number of immigrants affects the efficiency wage through:

$$
\begin{aligned}
\frac{\partial w}{\partial N_{F}} & =w_{o}\left(\frac{\left(1-\frac{\partial L}{\partial N}\right) L-\frac{\partial L}{\partial N}(N-L)}{L^{2}}\right)+\frac{e}{q}\left(\frac{\partial f_{L}\left(\frac{L}{N}\right)}{\partial N} \frac{\frac{\partial L}{\partial} N-L}{N^{2}} \frac{N_{L}}{\left(N_{L}-L_{L}\right)}\right) \\
& =w_{o}\left(\frac{(1-\eta) L}{L^{2}}\right)+\frac{e}{q}\left(\frac{\partial f_{L}\left(\frac{L}{N}\right)}{\partial N} \frac{L(\eta-1)}{N^{2}} \frac{N_{L}}{\left(N_{L}-L_{L}\right)}\right.
\end{aligned}
$$

There are two countervailing effects on willingness of workers to exert effort. ${ }^{14}$ More immigrants increase the tax levied on employed workers, which

\footnotetext{
${ }^{13}$ There are $N-L=\left(N_{L}+N_{F}-\left(L_{L}+L_{F}\right)\right)$ unemployed workers and $\left(L_{L}+L_{F}\right)$ employed workers.

${ }^{14}$ Since $\frac{\partial f_{L}\left(\frac{L}{N}\right)}{\partial N}>0$ and $\eta<1$.
} 
reduces willingness-to-exert effort. However, as the number of immigrants increases, the threat of dismissal to local workers increases, which increases employed workers' willingness to exert effort.

A necessary and sufficient condition for immigration to increase the willingness of the local individuals to exert effort is

$$
\frac{\partial w}{\partial N_{F}}=w_{o}\left(\frac{(1-\eta) L}{L^{2}}\right)+\frac{e}{q}\left(\frac{\partial f_{L}\left(\frac{L}{N}\right)}{\partial N} \frac{L(\eta-1)}{N^{2}} \frac{N_{L}}{\left(N_{L}-L_{L}\right)}<0\right.
$$

We therefore establish an upper bound to welfare benefits consistent with more immigrants increasing willingness-to-exert effort; that is, an upper bound to more immigrants increasing the discipline on employed workers. Welfare benefits cannot exceed

$$
w_{o}<\frac{e}{q}\left(\frac{\partial f_{L}\left(\frac{L}{N}\right)}{\partial N}\left(\frac{L}{N}\right)^{2} \frac{N_{L}}{\left(N_{L}-L_{L}\right)}\right)
$$

Clearly, welfare benefits that are too high blunt the disciplining effect of an increase in the size of the reserve army. The taxes levied on employed workers to finance welfare payments also at the same time make effort exertion less attractive. ${ }^{15}$

We can establish a lower bound to welfare benefits $\underline{w}$ as the payment required for the location be sufficiently attractive to immigrants; otherwise, they would not emigrate, or would go elsewhere to receive welfare benefits.

The lower and upper bounds to welfare payments establish the condition that ensures that more immigrants will increase effort-willingness: ${ }^{16}$

$$
\underline{w}<w_{o}<\bar{w}=\frac{e}{q}\left(\frac{\partial f_{L}\left(\frac{L}{N}\right)}{\partial N}\left(\frac{L}{N}\right)^{2} \frac{N_{L}}{\left(N_{L}-L_{L}\right)}\right)
$$

\footnotetext{
${ }^{15}$ See the appendix.

${ }^{16}$ See the appendix.
} 
We can summarize:

Willingness to exert effort is contingent on the taxes that are paid to finance welfare payments; if welfare payments are in the range determined by (27), immigration increases discipline on employed workers.

Increased immigration increases the number of employed immigrants, as well as the number of unemployed immigrants who receive welfare benefits:

$$
\frac{\partial \bar{w}}{\partial N_{F}}=\frac{e}{q}\left(\frac{\partial f_{L}\left(\frac{L}{N}\right)}{\partial N} \frac{N_{L}}{\left(N_{L}-L_{L}\right)}\right) 2\left(\frac{L^{2}}{N^{3}}\right)(\eta-1)
$$

Increasing the number of immigrants also increases the proportion of unemployed workers in the total population.

We now have two further conclusions:

If welfare benefits are sufficiently high, or the number of immigrants is sufficiently large, immigrants displace the local employed population.

The upper bound on welfare benefits decreases with the number of immigrants.

\section{Low welfare benefits for immigrants}

Unemployed immigrants choose to stay in the country only if welfare benefits exceed $\underline{w}$. If opportunities elsewhere are not attractive, and immigrants receive differentially low welfare benefits, immigrants may be placed in a position of offering to join the labor force at any wage offered. National workers, if they receive higher welfare benefits, at the same time do not mind being unemployed as much as immigrants. From equation (12), national workers' willingness-to-exert-effort is a function of the efficiency wage: $L_{L}=v_{L}(w)$. The total willingness-to-exert-effort function is the aggregate of the local labor force plus immigrants now willing to work at any wage,

$$
L^{s}=L_{L}+L_{F}=v_{L}(w)+N_{F}
$$


where $N_{F}$ is the number of immigrants. The increase in labor supply due to the presence of immigrants decreases the equilibrium efficiency wage and now also decreases employment of local workers. There is now no source of gain from immigration for national workers. We conclude:

If welfare benefits for immigrants are discriminately low, immigrants displace local workers in employment, and national workers cannot gain from immigration.

\section{Policies}

We now consider the choice of policies. Governments can choose welfare payments, and the number of immigrants who are legally present and qualify for welfare benefits. ${ }^{17}$ We can suppose that policy is chosen to maximize social welfare

$$
W=W\left(U_{k}, E_{L}(V)\right)
$$

where $U_{k}$ is the utility of capital owners and $E_{L}(V)$ is the expected utility of national workers.

We shall presently observe, however, that (30) need not be interpreted as social welfare. If policies are not beneficial to both labor and owners of capital, then $W$ can have the interpretation of political support.

Both capital owners and workers have positive social (or political) weights:

$$
W_{E_{L}}=\frac{\partial W(.)}{\partial E_{L}}>0, \quad W_{U_{k}}=\frac{\partial W(.)}{\partial U_{k}}>0
$$

The utility of immigrants is not included in $W$. The number of immigrants is rather a policy decision affecting the utilities of national residents. We can view immigrants are better off as a consequences of their presence. Their presence is

\footnotetext{
${ }^{17}$ The phenomenon of illegal immigration (see for example Ethier 1986, Djajić, 1997) indicates that government is not always able to regulate immigration. Legality is however a requisite for receipt of welfare benefits. See also Hillman and Weiss (1999) on "permissible illegality"; Hillman and Weiss propose sectoral confinement of immigrants as a reason for selective enforcement of immigration regulations. Exclusion from welfare benefits may be another reason for a policy of allowing illegal immigrants to remain illegally present.
} 
voluntary, and, whether employed or recipients of welfare payments, their incomes are higher than in the locations they have left.

\section{The preferred policies of employers}

We saw in the previous section that, as the number of immigrants increases, the wage decreases and employment increases. ${ }^{18}$ However, also, for any level of welfare benefits, there is an upper bound to the number of immigrants who act as a discipline on employed workers. This upper bound decreases with the number of immigrants. $^{19}$

The utility of capital owners is increased by immigration, but within limits. We have seen that increasing welfare payments decreases workers' willingness to exert effort, because of the increased tax burden on workers. ${ }^{20}$ The decreased willingness to exert effort is to the disadvantage of owners of capital. Indeed, other effects aside, owners of capital, even though they do not finance the unemployment benefits, prefer zero welfare benefits, to maximize the discipline of unemployment on employed workers.

Employers therefore wish welfare benefits to be as low as possible, which is the lower bound set by the reservation income of immigrants i.e. $w_{0}=\underline{w}$. Employers also seek maximal presence of immigrants, which requires $\underline{w}=w_{0} \leq \bar{w}$. Hence employers seek a welfare-benefits policy of $\underline{w}=w_{0}=\bar{w}$. The preferred policies of capital owners are indicated at point $\mathrm{A}$ in figure 3 , where welfare benefits are set at $\underline{w}$ and the number immigrants is such that $\underline{w}=\bar{w} \cdot{ }^{21}$

The preferred policies of national workers

The expected utility of a national worker is

\footnotetext{
${ }^{18}$ From equation (25).

${ }^{19}$ See equation (28).

${ }^{20}$ See equations (12) and (16).

21 See equations (19) and (23). Since capital owners in practice themselves finance part of the welfare payments through taxes, this preference for the lower bound of welfare payments is reinforced.
} 


$$
E_{L}(V(w, e))=\left[\operatorname{Pr}_{j}\left(w^{*}-w_{o} \frac{N-L}{L}-e\right)+\left(1-\operatorname{Pr}_{j}\right) w_{0} \frac{1}{r}\right.
$$

$\operatorname{Pr}_{j}$ is here the probability of a national worker having a job with a wage of $w^{*}$ thus having utility $\left(w^{*}-w_{o} \frac{N-L}{L}-e\right)$.

A national worker is unemployed with probability $\left(1-P r_{j}\right)$, in which case he or she receives benefits of $w_{0}$ and exerts no effort $(e=0)$. The probability that a local worker is employed is, in the steady state, equal to the proportion of employed persons in the labor supply,

$$
\operatorname{Pr}_{j}=\frac{L_{L}^{*}}{N_{L}}
$$

Workers' preferred policies at B are established by

$$
\frac{E_{L}(V(w, e))}{\partial w_{o}}=0 \text { and } \frac{E_{L}(V(w, e))}{\partial N_{F}}=0
$$

The probability of being employed depends on welfare benefits and the number of immigrants. $^{22}$ Welfare benefits sought by national workers satisfy $\underline{w}<w_{0}<\bar{w}$, with a positive number of immigrants. ${ }^{23}$ The preferred policies of national workers are shown in figure 3 at point $B$, which shows the higher welfare benefits and fewer immigrants sought by workers compared to owners of capital.

\section{The contract curve}

Looking again at $\mathrm{A}$ and $\mathrm{B}$, we see that capital owners seek more immigrants than national workers and lower welfare benefits; they desire more immigration because of their direct benefit from a greater reserve army and the greater employment made possible by immigration; and they want lower welfare benefits because they wish to have greater worker discipline from the threat of unemployment. Workers wish to have lower immigration, because their benefit lies in their increased probability of their own employment (capitalists do not care who is employed,

\footnotetext{
${ }^{22}$ From (18) and (19).

${ }^{23}$ This is in an interior solution.
} 
national workers or immigrants); and workers wish to have higher welfare payments because there are states of the world in which they are unemployed. The utility of national workers declines with departures from the point B. Likewise, the utility of owners of capital declines with departures from the point A. The contract curve joining $\mathrm{A}$ and $\mathrm{B}$ is described by

$$
\frac{\partial W(.)}{\partial N_{F}}=W_{E_{L}(V(.))} \frac{\partial E_{L}(V(.))}{\partial N_{F}}+W_{U_{k}(.)} \frac{\partial U_{k}(.)}{\partial N_{F}}=0
$$

and

$$
\frac{\partial W(.)}{\partial w_{0}}=W_{E_{L}(V(.))} \frac{\partial E_{L}(V(.))}{\partial w_{0}}+W_{U_{k}(.)} \frac{\partial U_{k}(.)}{\partial w_{0}}=0
$$

A government maximizing $W$ will choose a point along $\mathrm{AB}$. The point chosen will indicate the social compromise, and will reflect the social weights of the two parts of the society.

\section{Immigration policy when welfare benefits are pre-determined}

We can take welfare payments as pre-determined by social norms that define the responsibility of government to its citizens. We denote the pre-determined welfare benefits as $w_{0}$ '. Then, with these welfare benefits, at a given level of social welfare,

$$
d W=\frac{\partial W(.)}{\partial E_{L}\left(V\left(N_{F}, w_{0}{ }^{\prime}\right)\right)} d E_{L}\left(V\left(N_{F}, w_{0}{ }^{\prime}\right)\right)+\frac{\partial W(.)}{\partial U_{k}\left(N_{F}, w_{0}{ }^{\prime}\right)} d U_{k}\left(N_{F}, w_{0}{ }^{\prime}\right)=0
$$

and

$$
\frac{d E_{L}\left(V\left(N_{F}, w_{0}{ }^{\prime}\right)\right)}{d U_{k}\left(N_{F}, w_{0}{ }^{\prime}\right)}=-\frac{\frac{\partial W(.)}{\partial U_{k}\left(N_{F}, w_{0}{ }^{\prime}\right)}}{\frac{\partial W(.)}{\partial E_{L}\left(V\left(N_{F}, w_{0}{ }^{\prime}\right)\right)}}<0
$$

In Figure 4 we show a utility-possibility frontier derived from the contract curve. Movements from the origin along the frontier indicate increased numbers of immigrants. Along the segment $\mathrm{OB}$, national workers and owners of capital both benefit from increased presence of immigrants. Point B in figure 4 corresponds to B 
in figure 3, where the number of immigrants maximizes national workers' expected utility. Beyond B, the expected utility of workers declines.

The utility of capital owners continues to increase, however, beyond B. Figure 4 shows two possibilities for capitalists' preferred immigration at the points $\mathrm{A}_{l}$ and $\mathrm{A}_{2}$.

When the utility-possibility frontier is $O B A_{l}$, the policy choice is at a point such as $C_{l}$, where workers and owners of capital have both gained from the presence of the immigrants. When the utility-possibility frontier is $\mathrm{OBA}_{2}$, there exist both mutually beneficial policies and also policies where owners of capital gain but workers lose from immigration. A policy choice at $C_{2}$ provides mutual gain and social harmony. The policy choice at $C_{3}$ results in excessive immigrants for national workers (whose expected utility has declined relative to the no-immigration origin).

If $O B A_{1}$ is the utility-possibility frontier, we can interpret a government as maximizing social welfare at $C_{1}$. Similarly, if $O B A_{2}$ is the utility-possibility frontier, a policy choice at $C_{2}$ is also consistent government as maximizing social welfare. A policy choice at $C_{3}$ is not consistent with social welfare maximization, since the policy chosen has decreased welfare of some of the government's citizens (the workers).

A policy choice at $C_{3}$ is consistent with positive social weight on the utility of workers. If workers did not have positive weight, the policy chosen would be yet greater immigration, at the preferred policy of capital owners $\mathrm{A}_{2}$.

If however $C_{3}$ is the chosen policy, we may prefer not to view the government as maximizing social welfare, since the utility of workers has declined because of the policy decision. Such a policy may be more consistent with an interpretation of $W$ a political-support objective rather than a social welfare objective.

Whether a government is maximizing the social welfare of its population or maximizing political support from domestic constituencies, the choice of the number of immigrants present is greater than the number of immigrants sought by national workers (at the point A). Workers can be expected to complain that there are too many immigrants. Nonetheless workers have gained from the presence of the unemployed immigrants. 
We conclude:

When the policy issue is how many immigrants on welfare should be present, neither workers nor owners of capital are satisfied with a social-welfare maximizing or political-support maximizing policy. Workers and capital owners can however be in social harmony on the issue whether unemployed immigrants receiving welfare payments should be present.

Furthermore:

If the policy decision results in an outcome where workers and owners of capital are not in social harmony on the issue whether unemployed immigrants on welfare should be present, there exist policy options that permit social harmony to be achieved.

\section{Concluding remarks}

When unemployment is an involuntary consequence of efficiency wages, some people have the fate to have no economic role other than to act as an efficiency discipline on employed workers. Karl Marx viewed this disciplining mechanism as an employer conspiracy; in the modern efficiency-wage version of the unemployment-asdiscipline argument, the discipline is the outcome of Nash equilibrium among employers. We have considered the logical implications when immigrants arrive in a society and compose (disproportionately) the disciplining reserve army.

We have not been able completely to suppress overtones of Marx's conspiracy against labor. Elements of the Marxian conspiracy remain present, since policy outcomes benefiting owners of capital at the expense of labor may be feasible. Nonetheless, policies exist that permit national workers to benefit from the presence of immigrants on welfare, even if national workers themselves exclusively finance welfare payments. If there is not social harmony, policies are therefore feasible that, by providing mutual gain for national workers and owners of capital, can ensure an outcome of social harmony. Our model of social harmony is an alternative to the 
more socially divisive perspective on the same circumstances offered by the Samaritan's dilemma.

An alternative to both the Samaritan's dilemma and to the unemployment-asdiscipline model is the insider-outsider model, which describes unemployment as due to rent protection by employed labor. ${ }^{24}$ We can suppose that Karl Marx would have been prepared to consider the plausibility of the insider-outsider hypothesis, with its collusive division of capitalist rents. He would however perhaps have been uncomfortable with the lack of worker solidarity in the model, where employed workers exploit unemployed workers. The efficiency-wage explanation, which takes the view that unemployment is due to rent protection for owners of capital, is entirely consistent with Marxian theory. There is more optimism in the efficiency-wage model than in Marx, since the discipline provided by the reserve army leads employed workers to receive higher wages and to work more productively.

Since immigrants are voluntarily present to populate the disciplining reserve army, our model has no place for claims of exploitation. In the model, as we can suppose to the case in practice, unemployed immigrants are better off unemployed and receiving welfare payments in their new location than they would be back in their home countries; otherwise they would not have emigrated. ${ }^{25}$ The unemployed immigrants have improved their well-being. We have established that conditions exist whereby unemployed workers are better off, and owners of domestic capital are certainly better off. Hence the social harmony.

Finally, fairness to Buchanan and his Samaritan-parasite game requires us to observe that our model of social harmony presumes that immigrants wish to work but are involuntarily excluded from employment in the efficiency-wage unemployment equilibrium. Evidence that the immigration reflects locational adverse selection and that immigrants do not intend to work but arrive with the sole intent of enjoying welfare benefits, would compromise our model of social harmony, and would resuscitate Buchanan's socially less appealing model. Since immigrants could not be a credible efficiency-enhancing discipline in the domestic labor market.

\footnotetext{
${ }^{24}$ The efficiency-wage and insider-outsider theories are not logically contradictory. See Lindbeck and Snower 1991.

${ }^{25}$ We have not considered emigration that is due to force-majeure in the home country. On involuntary emigration for economic reasons, see for example Epstein, Hillman, and Ursprung (1999).
} 


\section{Appendix}

We here derive the conditions under which increasing the number of immigrants results in an efficiency-wage equilibrium where wages fall and the number of local employed workers increases. The local willingness-to-exert-effort function depends upon the wage level and the willingness-to-exert-effort function of immigrants: $L_{L}\left(w, L_{F}\right)$. The willingness-to-exert-effort function of the immigrants depends on the wage level and the number of immigrants entering the country, $a$ : $L_{F}(w, a)$. It is the case that increasing the wage increases willingness-to-exert effort of both the local workers and of the immigrant. Moreover, increasing the number of immigrants increases the local willingness-to-exert-effort function and increasing the number of immigrants entering the country increases the willingness-to-exert-effort function of the immigrants. Thus,

and

$$
\begin{gathered}
L_{w}=\frac{\partial L_{L}\left(w, L_{F}\right)}{\partial w}>0 ; \tilde{L_{F}}=\frac{\partial L_{L}\left(w, L_{F}\right)}{\partial L_{F}}>0 \\
F_{w}=\frac{\partial L_{F}(w, a)}{\partial w}>0 \text { and } F_{a}=\frac{\partial L_{F}(w, a)}{\partial a}>0 .
\end{gathered}
$$

In equilibrium the demand for labor, $D(w)$, equals the aggregate willingness-to-exert effort:

$$
L_{L}\left(w, L_{F}\right)+L_{F}(w, a)=D(w)
$$

The total differential of (A1) with respect to the number of immigrant is:

$$
L_{w} \frac{d w}{d a}+\tilde{L_{F}} \frac{d F}{d a}+F_{w} \frac{d w}{d a}+F_{a}=D_{w} \frac{d w}{d a}
$$


where $F=L_{F}(w, a)$ and $D_{w}=\frac{\partial D(w)}{\partial w}<0$.

Rewriting the equilibrium condition (A2):

$$
\frac{d w}{d a}=\frac{\tilde{L_{F}} F_{a}+F_{a}}{D_{w}-L_{w}-F_{w}}<0
$$

Thus: increasing the number of immigrants decreases the equilibrium wage.

We now consider the effect of a change in number of immigrants on the equilibrium size of the local employed workforce:

$$
\frac{d L}{d a}=L_{w} \frac{d w}{d a}+\tilde{L_{F}}\left(F_{w} \frac{d w}{d a}+F_{a}\right)=\frac{d w}{d a}\left(L_{w}+\tilde{L_{F}} F_{w}\right)+\tilde{L_{F}} F_{a}
$$

Using (A3) together with (A4) we obtain:

$$
\begin{aligned}
\frac{d L}{d a} & =\frac{\tilde{L_{F}} F_{a}+F_{a}}{D_{w}-L_{w}-F_{w}}\left(L_{w}+\tilde{L_{F}} F_{w}\right)+\tilde{L_{F}} F_{a} \\
& =\frac{L_{w} F_{a}+D_{w} L_{a} \tilde{L_{F}}}{D_{w}-L_{w}-F_{w}}
\end{aligned}
$$

The denominator is negative. So in order for an increase in the number of immigrants to increase the equilibrium number of local employed workers, we require that:

$$
L_{w} F_{a}+D_{w} L_{a} \tilde{L}_{F}<0
$$

Rewriting (A6) we have:

$$
\eta_{L}^{S} \frac{F_{a}}{L_{a} \tilde{L}_{F}}<-\eta^{D}
$$


where $\eta_{L}^{S}$ is the elasticity of the willingness-to-exert effort and $\eta^{D}$ is the elasticity of demand (which is negative). Equation (A7) describes whether an increase in the number of immigrants increases the number of local employed workers. The outcome is ambiguous, and depends on the elasticities of demand and willingness-to-exerteffort function. If (A7) does not hold, increasing the number of migrants will decrease the number of employed local workers; although the decrease in the number of employed workers will be lower than the increase in the number of immigrants. 


\section{References}

Andreoni, James, R. 1990. Impure altruism and donations to public goods: A theory of warm-glow giving. Economic Journal 100, 464-77.

Buchanan, James M., 1975. The Samaritan's dilemma. In Edmund Phelps, ed., Altruism, Morality and Economic Theory, Russell Sage, New York.

Djajić, Slobodan, 1997. Illegal immigrants and resource allocation. International Economic Review 38, 97-117.

Epstein, G.S., A.L. Hillman and H. W. Ursprung, 1999, The king never emigrates. Review of Development Economics 3, 107-121

Ethier, Wilfred J., 1986. Illegal immigrants: The host country problem. American Economic Review 76, 56-71.

Hillman, Arye L. and Avi Weiss, 1999, A theory of permissible illegal immigration. European Journal of Political Economy 15, 585-604.

Konrad, Kai. A., 1994. The strategic advantage of being poor: Public and private provision of public goods. Economica 61, 79-92.

Lindbeck, Assar and Dennis Snower, 1988. The Insider and Outsider Theory of Employment and Unemployment, MIT Press, Cambridge Mass.

Lindbeck, Assar and Dennis Snower, 1991. Interactions between the efficiency wage and insider-outsider theories. Economics Letters 37, 193-196.

Lindbeck, Assar, 1994. The welfare state and the employment problem, American Economic Review, papers and proceedings 84, 71-75.

Lindbeck, Assar, Sten Nyberg, and Jorgan W. Weibull, 1997. Social norms and economic incentives in the welfare state, Quarterly Journal of Economics $114,1-35$.

Marx, K., 1887 (original). Capital, A critical Analysis of Capitalist Production. Translated from the third German edition by Samuel Moore and Edward Aveling and edited by Frederick Engels. Progress Publishing, Moscow.

Schulze, Günther G., 2000. The Political Economy of Capital Controls, Cambridge University Press, New York.

Shapiro, C. and J. Stiglitz, 1984, Equilibrium unemployment as a worker discipline device. American Economic Review 74, 433-44.

Sinn, Hans-Werner, 1995. A theory of the welfare state. Scandinavian Journal of Economics 97, 495-526.

Snower, Dennis, J., 1993. The future of the welfare state. Economic Journal 103, 700-717.

Snower, Dennis J., 1996. What is the domain of the welfare state? In Mario Baldassari, Luigi Panganetto, and Edmund Phelps, eds., Equity, Efficiency, and Growth: The Future of the Welfare State, St Martins Press, New York. 
Weede, Erich, 1998. Is the market or the welfare state an escape-proof prison? In James M. Buchanan and Bettina Monissen, eds., The Economists' Vision, Campus, Franfurt and New York. 
Figure 1

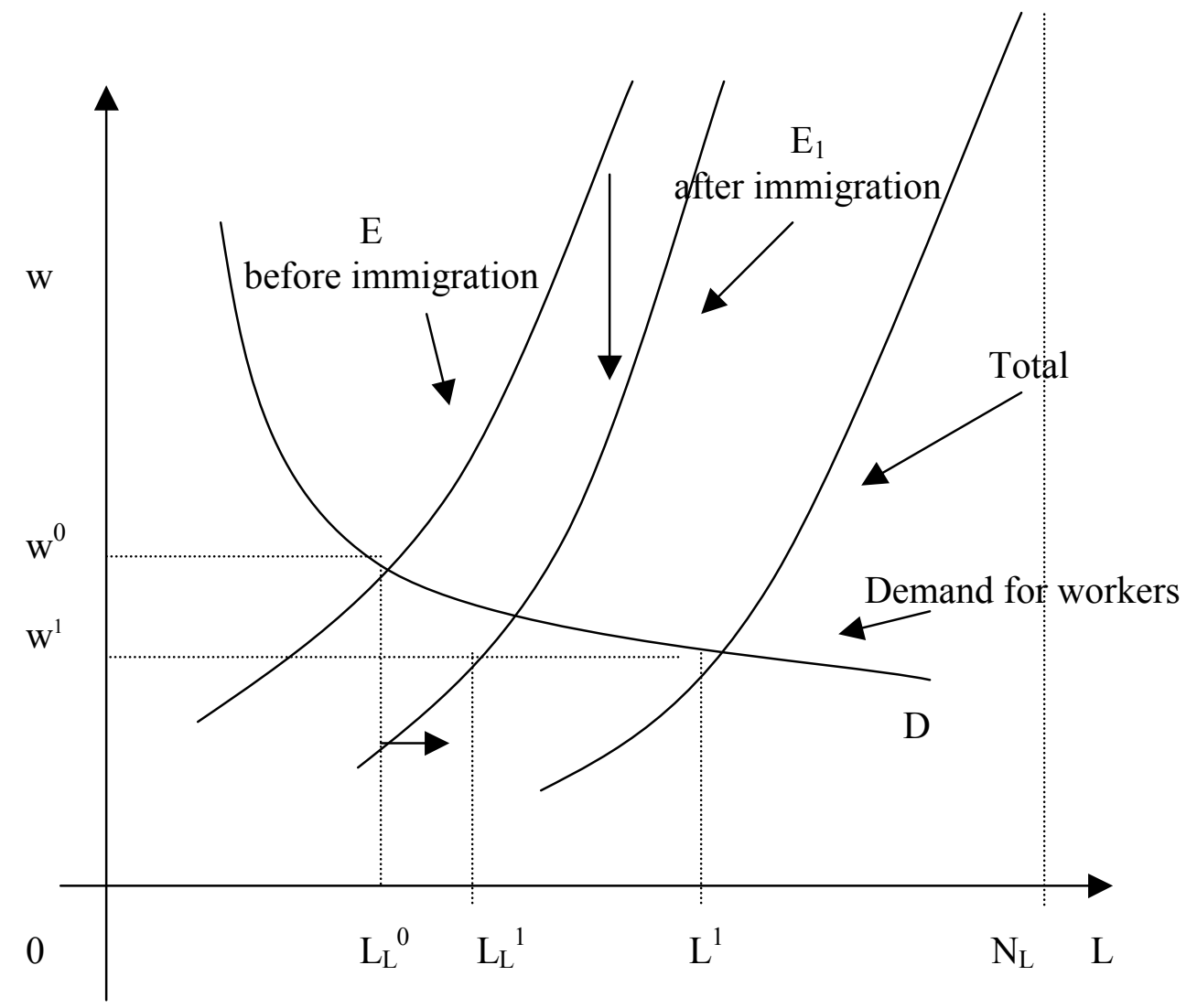


Figure 2

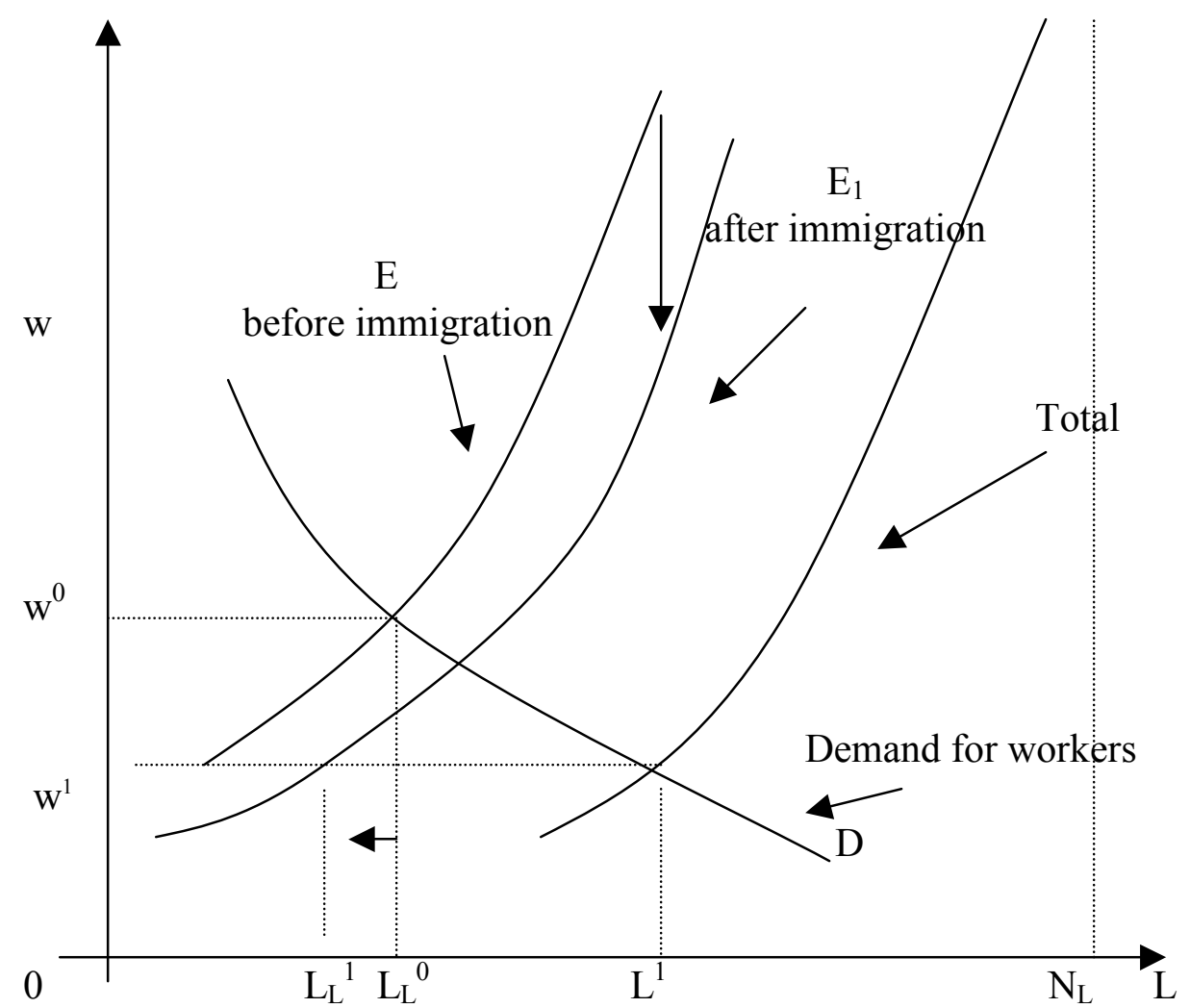




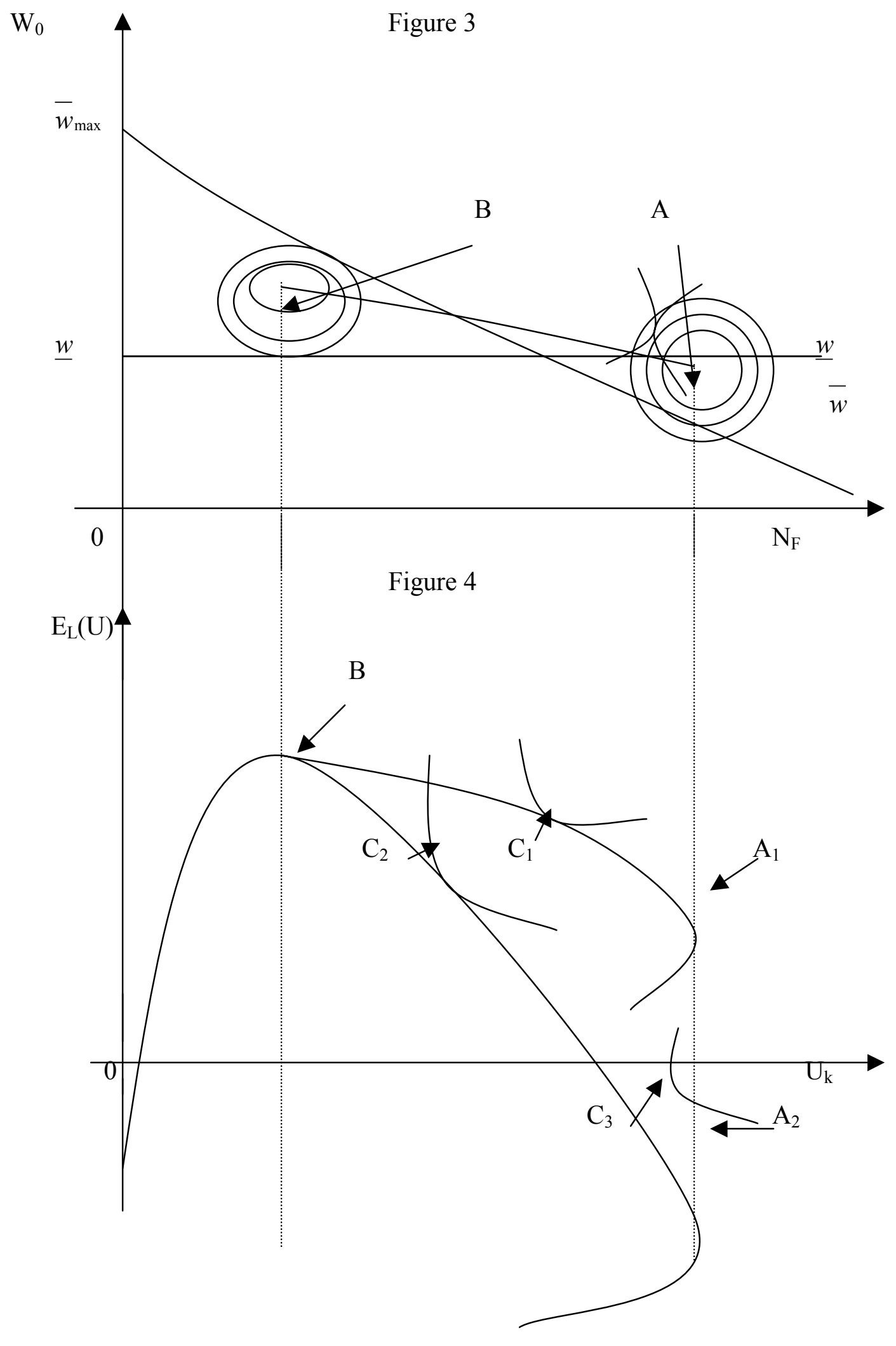




\section{IZA Discussion Papers}

No. Author(s)

71

72

L. Goerke

J. Fersterer

R. Winter-Ebmer

73

G. S. Epstein

S. Nitzan

74 M. Kräkel

75

B. Henry

M. Karanassou

D. J. Snower

76

G. Brunello

M. Giannini

77

C. M. Schmidt

78

J. Hansen

R. Wahlberg

79

J. S. Earle

Z. Sakova

80 J. C. van Ours

J. Veenman

81

T. J. Hatton

S. Wheatley Price

82 K. A. Konrad

83

R. Euwals

84

C. M. Schmidt

85 S. Pudney

M. A. Shields

86

J.P. Haisken-DeNew

C. M. Schmidt

87
Title

Area

Date

The Wedge

3

$11 / 99$

Are Austrian Returns to Education Falling Over

Time?

The Endogenous Determination of Minimum Wage 3

Strategic Mismatches in Competing Teams

5

Adjustment Dynamics and the Natural Rate: An 1

Account of UK Unemployment

Selective Schools

5

Knowing What Works: The Case for Rigorous

Program Evaluation

Endogenous Schooling and the Distribution of the Gender Wage Gap

Entrepreneurship from Scratch: Lessons on the Entry Decision into Self-Employment from Transition Economies

The Netherlands: Old Emigrants - Young Immigrant Country

Migration, Migrants and Policy in the United Kingdom

Privacy, time consistent optimal labor income taxation and education policy

Female Labour Supply, Flexibility of Working Hours, 1 and Job Mobility in the Netherlands

The Heterogeneity and Cyclical Sensitivity of 1 Unemployment: An Exploration of German Labor Market Flows

Gender and Racial Discrimination in Pay and 5/6 Promotion for NHS Nurses

Money for Nothing and Your Chips for Free?

5 The Anatomy of the PC Wage Differential

Educational Mismatch and Wages in Germany
5

$11 / 99$

$11 / 99$

$12 / 99$

$12 / 99$

$12 / 99$

$12 / 99$

$12 / 99$

$12 / 99$

$12 / 99$

$12 / 99$

$12 / 99$

$12 / 99$

12/99

$12 / 99$

$12 / 99$

$12 / 99$ 
P. Cahuc

A. Zylberberg

97

A. Barrett

98

J.P. Haisken-DeNew

C. M. Schmidt

L. Husted

H. S. Nielsen

M. Rosholm

N. Smith
G. Brunello
C. Graziano
B. Parigi

Migration in Spain: Historical Background and 1 Current Trends

Aliyah to Israel: Immigration under Conditions of 1 Adversity

Tenures that Shook the World: Worker Turnover in $\quad 4$ Russia, Poland and Britain

Identification and Estimation of Causal Effects of 6 Multiple Treatments Under the Conditional Independence Assumption

The Rate of Return to Private Schooling

An Evaluation of Public-Sector-Sponsored

\section{Germany}

An Evaluation of Public Employment Programmes 6 in the East German State of Sachsen-Anhalt

Job Protection, Minimum Wage and Unemployment 3

Irish Migration: Characteristics, Causes and 1

Industry Wage Differentials Revisited: A

Longitudinal Comparison of Germany and USA

Residential Location and Youth Unemployment: 1

The Economic Geography of School-to-Work-

Transitions

Immigrant Assimilation and Welfare Participation: 1/3

Do Immigrants Assimilate Into or Out-of Welfare?

Employment and Wage Assimilation of Male First 3 Generation Immigrants in Denmark

Labor Supply and Matching Rates for Welfare

Characteristics

Estimation in a Duration Model for Evaluating

Matching Model with Uncertainty -

An Extension of Mortensen and Pissarides (1994)

Ownership or Performance: What Determines 1 
1979 - 1990: An analysis of the (West-)German multivariate failure times and unobserved heterogeneity

107 J. C. van Ours G. Ridder

J. Boone

J. C. van Ours

G. J. van den Berg

B. van der Klaauw

110 D. DeVoretz

C. Werner

111 V. Sorm

K. Terrell

L. Bellmann

T. Schank

113 R. Euwals

114 G. Brunello

A. Medio

115 A. Cigno

F. C. Rosati

116 C. Belzil

117 S. Bender

A. Haas

C. Klose

118 M. A. Shields

M. E. Ward

119 A. Lindbeck

D. J. Snower

120 P. T. Pereira

P. S. Martins

121 J. C. van Ours

122 D. Munich

J. Svejnar

K. Terrell

123 J. Hunt
Fast Track or Failure: A Study of the Completion

Rates of Graduate Students in Economics

Modeling Financial Incentives to Get Unemployed Back to Work

Combining Micro and Macro Unemployment

Duration Data

A Theory of Social Forces and Immigrant Second

Language Acquisition

Sectoral Restructuring and Labor Mobility:

A Comparative Look at the Czech Republic

Innovations, Wages and Demand for

Heterogeneous Labour: New Evidence from a

Matched Employer-Employee Data-Set

Do Mandatory Pensions Decrease Household

Savings? Evidence for the Netherlands

An Explanation of International Differences in

Education and Workplace Training

Why do Indian Children Work, and is it Bad for

Them?

Unemployment Insurance and Subsequent Job

Duration: Job Matching vs. Unobserved

Heterogeneity

IAB Employment Subsample 1975-1995.

Opportunities for Analysis Provided by the

Anonymised Subsample

Improving Nurse Retention in the British National

Health Service: The Impact of Job Satisfaction on

Intentions to Quit

The Division of Labor and the Market for

Organizations

Does Education Reduce Wage Inequality?

Quantile Regressions Evidence from Fifteen

European Countries

Do Active Labor Market Policies Help Unemployed Workers to Find and Keep Regular Jobs?

Returns to Human Capital under the Communist

Wage Grid and During the Transition to a Market

Economy

Why Do People Still Live in East Germany?
3

5

$2 / 00$

5

$2 / 00$

5

$2 / 00$

$1 / 00$

$1 / 00$

$1 / 00$

$2 / 00$

$2 / 00$

$2 / 00$

$2 / 00$

$2 / 00$

$2 / 00$

$2 / 00$

$2 / 00$

7

/00

$3 / 00$

$4 / 6$

4

$3 / 00$ 
Rational Poverty or Poor Rationality? The Take-up

125 F. Büchel

J. R. Frick

of Social Assistance Benefits

The Income Portfolio of Immigrants in Germany - $\quad 1 / 3$

$3 / 00$

Effects of Ethnic Origin and Assimilation. Or:

Who Gains from Income Re-Distribution?

126 J. Fersterer

R. Winter-Ebmer

Smoking, Discount Rates, and Returns to

Education

127 M. Karanassou

D. J. Snower

Characteristics of Unemployment Dynamics: The

Chain Reaction Approach

128 O. Ashenfelter

Do Unemployment Insurance Recipients Actively

Seek Work? Evidence From Randomized Trials in

D. Ashmore

O. Deschênes

129 B. R. Chiswick

M. E. Hurst

130 G. Brunello

S. Comi

C. Lucifora

Four U.S. States

The Employment, Unemployment and

Unemployment Compensation Benefits of

$1 / 3 \quad 3 / 00$

Immigrants

The Returns to Education in Italy: A New Look at $5 \quad 3 / 00$

the Evidence

Are Immigrants Favorably Self-Selected? An $\quad 1 \quad 3 / 00$

Economic Analysis

Hours and Wages in the Depression: British $7 \quad 3 / 00$

Engineering, 1926-1938

Paid and Unpaid Overtime Working in Germany and $1 \quad 3 / 00$

133 D. N. F. Bell

R. A. Hart

O. Hübler

W. Schwerdt

134 A. D. Kugler

G. Saint-Paul

135 A. Barrett

P. J. O'Connell

the UK

Hiring and Firing Costs, Adverse Selection and

3

$3 / 00$

Long-term Unemployment

Is There a Wage Premium for Returning Irish

1

$3 / 00$

Migrants?

136 M. Bräuninger

M. Pannenberg

Unemployment and Productivity Growth: An

3

$3 / 00$

Empirical Analysis within the Augmented Solow

Model

137 J.-St. Pischke

Continuous Training in Germany

$3 / 00$

138 J. Zweimüller

R. Winter-Ebmer

Firm-specific Training: Consequences for Job

Mobility

139 R. A. Hart

Y. Ma

Wages, Hours and Human Capital over the

Life Cycle

5

$3 / 00$

Education and Earnings Growth: Evidence from 11

European Countries

The Effects of Public Sector Sponsored Training on

Individual Employment Performance in East

$4 / 00$ 

both Worlds?

$\begin{array}{cl}145 & \text { M.-S. Yun } \\ 146 & \begin{array}{l}\text { T. K. Bauer } \\ \text { J.P. Haisken-DeNew }\end{array} \\ 147 & \begin{array}{l}\text { M. Belot } \\ \text { J. C. van Ours }\end{array}\end{array}$

Decomposition Analysis for a Binary Choice Model

Does the Recent Success of Some OECD

Microeconometric Evaluation of the Active Labour 6 Market Policy in Switzerland

The Duration of Immigrants' Unemployment Spells: $\quad 1 / 3 \quad 5 / 00$

155 J. Hansen

156 C. Dustmann Evidence from Sweden

Language Proficiency and Labour Market Per- 1

M. Jäntti

O. Raaum

E. Österbacka

Finland, Norway and Sweden Compared to the United States 

Models: The Case of the Self-Employed and the Increase in the Schooling Premium in the 1980's

161 V. Gimpelson

Public Employment and Redistributive Politics:

4

D. Treisman

Evidence from Russia's Regions

G. Monusova

162 C. Dustmann

M. E. Rochina-

Selection Correction in Panel Data Models: An

6

$6 / 00$

Barrachina

Application to Labour Supply and Wages

163 R. A. Hart

Y. Ma

Why do Firms Pay an Overtime Premium?

5

$6 / 00$

164 M. A. Shields

Racial Harassment, Job Satisfaction and Intentions

5

$6 / 00$

S. Wheatley Price

to Quit: Evidence from the British Nursing Profession

165

P. J. Pedersen

Immigration in a High Unemployment Economy: The Recent Danish Experience

166 Z. MacDonald

The Impact of Alcohol Consumption on Occupa- 5 tional Attainment in England

Earnings Inequality, Returns to Education and 5 Immigration into Ireland

167 A. Barrett

J. FitzGerald

B. Nolan

168 G. S. Epstein

A. L. Hillman

Social Harmony at the Boundaries of the Welfare 3 State: Immigrants and Social Transfers 